\title{
NORTHEAST ASIAN SECURITY
}

\section{S.Galsanjamts}

Nowadays, the security situation in the NEA is more predictable due to relative stable condition emerged after Cold War, collective search for multilateral security mechanism and growing interdependence and international processes in the region.

There are several factors which affect the security situation in NEA.

- Relations between the major powers

- Situation on Korean Peninsula

- Emerging China

In relations among the major powers we can emphasize two axes similar, to some extent, to the old system, the alliance relationship between USA and Japan, USA and South Korea, on one hand, and strategic partnership relations between RF and PRC, on the other hand. However, principle contradiction between these two axes is not evident except the different position on TMD program.

The US-Japan alliance cooperation based on mutual security arrangement is considered as the only bilateral security mechanism in the region. Moreover, most of the regional countries accept the US military presence in East Asia as a stabilizing factor for peace and security. In connection with the recent positive political process on Korean Peninsula there might appear a question about need and wisdom of keeping significant American forces in NEA. In our view, there will be no reason for total withdrawal of US forces from the region in decades to come, except adjustment in numbers, missions and capabilities.

US policy toward China has two directions. First, the US see China as an emerging competing power that might cause potential threat to its national interests in the Asia Pacific Region . Secondly, Washington pursues the policy of collaborating with PRC as with one of the undeniable factors for peace and security cooperation in the region.

China-s policy toward the security situation in the NEA:

- Beijing-Moscow strategic partnership is a model of security relations

- Alliance is considered as a Cold War thinking

- No hegemony or power politics

- Strong reaction to Taiwanese independence aspiration

S. GALSANJAMTS is Deputy Director, Institute for Strategic studies. 
- No further US military presence in East Asia

The current comprehensive strategic partnership relations between Russia and China are based on their common position against the influence of the sole superpower-USA as well as on their overall economic interests including arms trade. Arms trade is beneficial for Russia for its economic restoration and obtaining hard currency. For China-for its military modernization plans. In addition, both countries have been keeping similar position on Kosovo crisis and TMD.

However, there are some hidden factors which might have negative impact on further development of Sino-Russian relationships. Firstly, a problem of Chinese illegal immigration to the Russian Far East has reached the level when the local and central Russian authorities are almost ready to take drastic measures in due regard.

Secondly, with the stabilization of domestic economy and political situation Russia probably will try to retrieve its former great power interests and influence in the APR. That in turn will be contiguous to the China's interests. The last Century witnessed the exacerbation and normalization of Sino-Russian relations four times, and there is no guarantee that the situation would not appear again.

As of Russia Federation's stance toward US policy the following points are distinct:

- Concern with the NATO expansion to the EAST

- Against univocal world

- Negative posture toward TMD developing

- Against revising ABMT

Since the Russian economy has been suffering from a deep crisis, its military power except nuclear one has considerably weakened, particularly in Far East. In this sense, Russia both politically and militarily does not present any concern in NEA from the American point of view, so far. Such kind of situation has been assumed as a basis of the US-Russian relations.

The situation on Korean Peninsula. Coming out of its self-imposed hibernation for decades, North Korea has been engaged in a series of diplomatic initiatives to improve relations with foreign countries and join international forums in apparent efforts to draw foreign assistance.

Until the early spring of 2000, North Korea showed a little interest in having a talk with South Korea. Few people predicted the historic turning point in relations between two Koreas. A common expectation was that firstly US-DPRK 
relationship will be improved followed by acceleration in normalization process between North Korea and Japan.

Yet, South Korea's initiative in March 2000 when President Kim Dae-Jung proposed for the resumption government to government dialogue to discuss greater economic cooperation opened a new chapter in inter-Korean relationship. It included Seoul's commitment to assist the North in its efforts to rebuild its ailing economy, foster its agricultural sector and develop its infrastructure by providing loans to the North.

As I mentioned before there were some positive signs in the policy of DPRK leadership such as:

- Adherence to the US-DPRK Agreed Framework of 1994

- On-site inspection of Kumchangni Underground Facilities

- No additional provocation since Yellow Sea incident of 1999

- Moratorium on missile test

In addition, as a mean of alleviating its financial hardship, Pyongyang admitted about 180,000 South Korean tourists to scenic Mt. Kumgang, allowed more than 100 southern businesses to operate in its territory and increased trade with the South to $\$ 330$ million in 1999 . Moreover, DPRK began to carry out pragmatic approach to improve diplomatic relations. To mention some:

- Kim Jon-IPs visit to PRC

- New Treaty of Friendship with Russia

- Application for ARF Membership

- Normalization of relations with Italy and Australia

It was everybody's surprise when Seoul and Pyongyang announced the summit in April 2000. The North's acceptance of the Summit signaled a new sense of confidence that it could maintain its regime internally even while reaching outside for help. Six years after the death of his father, Kim Jon-11 must have felt he succeeded both in consolidating his own position at home and in building a political system essentially impermeable to outside influence.

Rather than taking the difficult steps in dealing with the USA, North Korea might have decided to look elsewhere for support. Such a move would not only hold the promise of obtaining additional free food and other economic assistance, but also provide North Korean leverage on the US. There is no doubt that both Koreas have crossed a bridge of no return, however. Whatever the motivation was, appearance of harmonious relations could not but have a positive effect on the political standing of both Kims, at home and abroad. Some critics argue that the summit announcement was a cynical reelection maneuver, or 
worse, a dangerous give-way. However, it is undeniable the summit has opened a line of communication between the top leaders, although it is premature to believe that mutual confidence has been built all of sudden and era of cooperation has arrived.

The historic inter-Korean summit, June 13-15, 2000, and Joint Declaration not only has opened a new chapter in reconciliation and cooperation between the two Koreas, but was the first step that has been taken on the long road to dismantle the Cold War structure on the Korean Peninsula, thereby laying the groundwork for eventual peaceful reunification of Korea.

The inter-Korean summit has several regional implications. First of all, it has a positive implication on the security situation not only of Korean Peninsula but of NEA as whole. The international structure surrounding the KP had reflected the post-Cold War characteristics, while inter-Korean relations had been reminiscent of the Cold War. In order to prevent the dual structure from developing into a more precarious one, the Kim Dae-jung government had opted for an engagement policy toward North Korea. Seoul sees the promotion of cultural, humanitarian and, most important, trade and economic ties as the best way to ease tensions and lay the groundwork for eventual reunification of the Peninsula. Secondly, if inter-Korean relations are improved through reconciliation and cooperation, they would contribute to resolving the North Korean missile issue. The test-firing of long-range missile pushed the US and Japan to agree on the research and development of TMD, which has raised very negative reaction from China and Russia, provoking a challenge among the regional powers.

Thirdly, the two Koreas will serve as a hub of NEA when inter-Korea cooperative project are completed as planned. Both of Koreas will emerge as a center of the region when the capital and technology of the South and cheap labor of the North will be joined. In addition, inter-Korea transport system will connect the South with those in China and Russia, which in turn, are connected to Europe.

Finally, inter-Korean summit talks would produce a normal triangular relationship between the US, South and North Korea.

The inter-Korean rapprochement followed by the acceleration of the DPRKJapan normalization talks and improvement in the US-DPRK relationship. Perhaps North Korea's acceptance of the Summit meeting can be interpreted as a realization by Pyongyang that it has gotten most of what it can get from the US without paying a big price. However, North Korea's top priority was put on the USA. If diplomatically recognized by the univocal superpower in the post Cold 
War era, North Korea can get an assurance of its regime survival.

For the very reason, Pyongyang dispatched Jo Myong-rok, Vice Marshal, and Kim Jon IPs right hand man, to Washington as his special envoy to improve the relations with the US. In the joint US-DPRK Communiquй, the two sides agreed that improved relations were needed to ensure peace between North and South and in the APR. The Communiquй surprised the world by stating President Clinton's possible visit to the North.

In its turn, Washington sent State Secretary Albright to explore Pyongyang's willingness to scale back north Korea's missile program, ease military tensions on the Peninsula and normalize relations with the US. Pyongyang had made casual suggestion that it would give its missile research program if other countries would launch its satellites into orbit. North Korea also wanted more foreign aid and investment to invigorate its stalled economy. It hoped to get off the State Department's list of terrorist sponsoring countries, which would open up economic assistance from international financial organizations. A package deal involving the launching by another country of North Korean satellites by arranging a consortium of countries to provide a fund is one option to be considered. But it would not be an easy solution, especially since Japan will be asked to pay when North Korean shorter range missile would main a real threat to Japan's security.

One of the main preconditions of the eventual reunification of two Koreas is the lifting NK's economy to the certain level, which will take, from the South's experts view, 20-30 years from now. Along with foreign aid and investment, it is extremely important to transfer North Korean economy to the market system.

Another important component of peaceful reunification is maintaining internal political stability of the DPRK. Comparative free foreign policy and liberalization of totalitarian economic system will demand certain level of democratic changes and openness from Pyongyang authority, which in turn might provoke domestic social instability and weakening of the political regime. We may predict strong struggle of ordinary citizens against Stalinist ruler, at least massive immigration flow to neighboring countries. In this scenario, a lot of things will depend on how Pyongyang act, and which side will will take military personnel of the Armed Forces.

It is quite interesting question that what kind of country will it be after peaceful reunification and what will be its position in the NEA and in international arena. Thanks to South Korean capital, high technology and cheap labor of the North the united Korea might appear as powerful economic state. Moreover, since both of countries are considered world $4^{\text {th }}$ and $5^{\text {th }}$ militarized states, it 
is also possible they will keep their military capability on certain level after unification. Due to very reason the united Korea may remain as a potential nuclear power. From these points of view, one can draw a picture of powerful, both economically and militarily, Korean state in decades to come, if the internal political and social stability of DPRK will be maintained and its economy will developed successfully.

On the other hand, if the reunification process will undergo before excepted time due to uncertainty which can not be managed, it will cost huge humanitarian and economic value, and notion of powerful unified Korea will disappear for a long.

Japan is certainly economically powerful state, but it has no sufficient military capability and political influence in the region. In order to overcome this posture Japan has began an active diplomatic efforts on international arena.

Tokyo intensified its efforts to affect the UN, including Security Council reform, pursuing its bid to become a permanent member of the Security Council. Japan sees its future to play a larger role in promoting disarmament and nonproliferation, economic development, and in the field of human security. Among the 189 UN member states, 141 countries reportedly expressed their support for Japan's proposal to expand the permanent and nonpermanent members in the Security Council.

On the regional level, there appear some shifts in Japan's attitude toward the region, gradually departing from its previous preoccupation with the US. Taking its economic and strategic consideration, Tokyo is cultivating ties with India, Iran and Pakistan. Japan's relation with China was in some degree strained, although the overall relationship is stable. China's increasing military spending, missile stockpiles and expanding naval operations near Japan caused considerable concern in the mind of Japan's policymakers. In this circumstance, Tokyo began reviewing its Official Development Aid to China, and postponed its planned \$161 million loan package.

There was little progress in Japan's negotiations with Russia over the Northern territory issue, despite its vigorous diplomatic efforts to realize the November 1997 Krasnoyarsk Agreement, in which both sides agreed to do the "utmost" to conclude a peace treaty by the year 2000. Even though, Russian President Putting confirmed that Russia would abide by the 1956 Joint Declaration, which stipulated the return of two disputed islands after conclusion of a peace treaty, it seems the Krasnoyarsk Agreement will not be realized in good time. 